\title{
Local community resistance in Lombok against tourism development policy
}

\section{Perlawanan masyarakat lokal di Lombok terhadap kebijakan pengembangan pariwisata}

\author{
Winengan \\ Department of Islamic Political Thought Study, Faculty of Ushuluddin and Religious Study, \\ Universitas Islam Negeri Mataram \\ Address: Jalan Pendidikan No. 35 Mataram, West Nusa Tenggara 83125 \\ E-mail: winengan@uinmataram.ac.id
}

\begin{abstract}
Since the enactment of decentralization policies regarding tourism management of regions, developing tourism areas have grown to become a central issue for the local government, who have tackled it through a land acquisition policy against local communities. This study intends to examine the formulation and process of government land acquisition policies for the development of tourism areas in Lombok, whose decisions are met with opposition from the local community. This research uses qualitative and snowball techniques to determine informants. Data collection is carried out in the form of interviews, documentation, and observation. The results of this study reveal that community resistance to tourism development policies is a clear example of the lack of the power the local communities have in the policy formulation process (which stipulates land acquisition as a formulation of its policies). In its formulation, regional tourism policies have undergone a systematic process. However, if the policy option does not reflect the results of a comprehensive study - which only considers economic and business benefits and is not participatory in providing space for local communities to articulate their interests - it will lack legitimization and will be met with resistance from the local community.
\end{abstract}

Keywords: marginalization; local community; policy formulation; resistance; tourism development

\begin{abstract}
Abstrak
Sejak diberlakukannya kebijakan desentralisasi pengelolaan pariwisata ke daerah, isu pengembangan kawasan pariwisata menjadi isu sentral yang banyak direspon Pemerintah Daerah melalui kebijakan pembebasan lahan masyarakat lokal. Penelitian ini bermaksud mengkaji proses perumusan kebijakan pembebasan lahan untuk pengembangan kawasan pariwisata di Lombok, yang keputusan kebijakannya masih mendapatkan penentangan masyarakat lokal sebagai penguasa lahan. Penelitian ini menggunakan metode kualitatif dengan teknik penentuan informan secara snow ball dan pengumpulan data dilakukan dengan teknik wawancara, studi dokumentasi, dan observasi. Hasil penelitian ini mengungkapkan bahwa resistensi masyarakat terhadap kebijakan pengembangan pariwisata merupakan implikasi dari marginalisasi kekuasaan dan kepentingan masyarakat lokal dalam proses perumusan kebijakan, yang menetapkan pembebasan lahan sebagai formulasi kebijakannya. Kebijakan pariwisata daerah lahir dari proses yang sistematis, namun jika pilihan kebijakan yang diadopsi tidak dilandasi hasil kajian secara komprehensif, yang hanya mempertimbangkan keuntungan ekonomi dan bisnis semata dan tidak partisipatif dalam memberikan ruang bagi masyarakat lokal untuk mengartikulasikankepentingannya, makaakanmelahirkankeputusankebijakanyangkuranglegitimasi, sehingga pilihan kebijakan tersebut sulit mendapatkan dukungan, tetapi justru menuai penolakan masyarakat lokal.
\end{abstract}

Kata kunci: marjinalisasi; masyarakat lokal; pengembangan pariwisata; perumusan kebijakan; resistensi

\section{Introduction}

Tourism development has become a strategic issue in regional development planning. With the autonomy of tourism management, many regions rely on tourism as the main sector in generating regional economies. However, the issue of tourism development is not independent. Instead, it always goes hand in hand with other issues because tourism is a fragmented industry that depends on other sectors, such as the environment, social culture, economy, community empowerment, and the sustainability of various aspects of regional development (Doods 2007). The significant impact of tourism on cultural, social and environmental conditions had caused changes in two main areas, 
namely social change in tourism areas and changes in priority and option of tourism policies. The presence of a policy model that combines those two changes is considered positive in a number of regions for the progress of sustainable tourism development (Tsartas 2003).

Tourism development as a series of efforts to promote integration in the use of various tourism resources and integrating all forms of aspects outside tourism that are directly or indirectly related to the continuity of tourism development, must be carried out through a complete, integrated and participatory system approach that covers several criteria such as economic, technical, socio-cultural, energy-saving, nature-preserving, and environmentally harmless. Every initiative that aims to develop tourism in the current context must consider sustainability as one of the important factors in constructing the desired type of tourism (Delgado \& Palomeque 2012). In this context, the existence of the tourism industry is suspected of being an activity with high intensity of coordination and competition, making it vulnerable to conflict among actors in tourism(Mwesiumo \& Halpern 2016:259).

At the local level, optimism for the growth and strategic role of tourism sector in regional economy has incited local governments with autonomy in tourism management (Wever 2012:67) issued numerous kinds of policies to support regional tourism growth and development. But in many cases, regional tourism development policies are suspected to not create community welfare and moderate the conflict resolution that hinder tourism development, but instead marginalize the community and provoke problems that affect the development of tourism in the region. Among the regional policies that often raise problems for tourism management systems in the regions and have brought various conflicts within the local communities, land acquisition for the benefit of tourism area development is the prominent one (Sin 2014). According to Manoppo's (2012) research, conflicts over regional tourism policies often involve elements of local government, tourism actors, and local communities. The emergence of conflicts in land acquisition policies is often triggered by unclear ownership issues, less affirmative usage for the benefit of local communities, and policy decisions for the land release which are considered to always harm the local community (Sidemen 2012). As a result, these policy decisions are often faced with resistance by the society. This phenomenon of tourism policy often occurs after the decentralization policy of tourism management to the regions, thus the existence of tourism in the region is considered to disadvantage local communities (Wever 2012).

The resistance of local community towards regional tourism development policy was also apparent in the case of land acquisition of the Mandalika Resort tourism area in Lombok, resulting in the stagnation of tourism facilities and buildings in the area. The local community perceived this policy as a form of marginalization as it had caused thousands of them to lose their houses and their occupation as farmers (SPI NTB 2014). This phenomenon of tourism development policy invigorate paradoxes of public policy that occurs in various regions where on one hand, it functions as conflict moderator by allocating resources to meet certain needs and values. But at the same time, it becomes a trigger for conflict itself due to the inability of the policy to manage the resource allocation process that can satisfy all parties (Subarsono 2016:3). Based on the tourism development policy in Lombok, this research is urgent to be carried out in order to understand the causes behind people's resistance to the presence of policies set by the state based on the perspective of public policy studies. This research study is focused on the process of policy making; arguing that the emergence of community opposition, as one of the interest groups (stakeholders) towards policy decisions that have been determined by the government, is because of interests that failed to be accommodated in the policy (Azhar 2013). This does not happen automatically, but because of the decision making process. The results of this study are expected to moderate the increase in regional tourism development policies performance, so that they always facilitate common goals of tourism stakeholders, and integrate all aspects of people's lives, economy, social and culture for the benefit of community welfare (Niekerk 2014).

\section{Research Methods}

This research is a policy research, which intends to examine the process of tourism development policy making that faced resistance from one of the stakeholder groups originating from the elements 
of the local community, with the constructivism paradigm, which is operationalized by qualitative methods. Informants who are used as the main information source are determined by snow ball sampling, consisting of nine people who each represents government officials involved as actors in the policy making process, representatives of the community as land owners, community leaders in the area, which begins with determining prominent informants, namely Head of Tourism Area Development Planning Office of Central Lombok Regency Culture and Tourism Office. Data mining is done by interviewing, documentation, and observation. Each data collected is analyzed with a soft system methodology approach, which is data analysis carried out by linking the substance of research between real worlds and systems thinking, the operationalization of which is carried out through stages: 1) The problem situation: unstructured, 2) The problem situation: expressed, 3) Root definitions of relevant, 4) Conceptual models, 5) Comparison of models and real world, 6) Changes: systemically desirable culturally feasible, 7) Action to improve the problem situation (Checkland 1993:162-183). In this study, stages 1 to 6 are used as a reference for the data analysis process, which includes data descriptions, data analysis, and preparation of research object concept models. To avoid data bias, the researcher is required to test the validity of the data based on data credibility criteria.

\section{Result and Discussion}

\section{Background of policy making}

The existence of tourism sector in Lombok is projected to lead regional economy developmentin order to bring welfare of the community (Disbudpar 2012). This idea originated from the unsolved problem of poverty of Lombok society through the agricultural policy of the local government and the delegation of tourism management authority to the regions, which was included in the Government Regulation of the Republic of Indonesia No.24 of 1979 concerning the Submission of Government Affairs in the Tourism Sector to the Level I Region or Province (Karim 2008).

As the first step to develop tourism in West Nusa Tenggara (NTB), the NTB Provincial Government appointed and defined several areas that are considered strategic as the main tourism area of NTB. Based on NTB Governor Decree No.133 of 1984 concerning the appointment of locations and land use arrangements for tourism development in NTB Province, the Mandalika area in Lombok is designated as one of NTB's leading tourism areas, which includes Kuta Hamlet, Seger Hamlet and Aan Hamlet. Kuta Hamlet is focused on Kuta Beach, Seger Hamlet is focused on Seger Beach. Bunut Beach and Siper Beach, and Aan Hamlet are focused on Pantai Aan (Disbudpar 2012).

The policy of determining the Mandalika Resort area in Lombok as a leading tourism area was also supported by the local community. The results of the study of local perceptions in regards to Mandalika Resort planning development area revealed that most (93.27\%) agreed, arguing that tourism development could provide employment opportunities for the community and could provide opportunities for the construction of various public facilities and activities held by surrounding community (BTDC 2012).

Those who disagreed (4.04\%) asserted that the development of tourism will automatically have an impact on the transfer of functions from the currently existing agricultural lands as well as residents' concerns about the possible disruption of security and social culture of the community (BTDC 2012). Taking into account the perception of the majority of local people supporting the development plan of tourism and the condition of the Mandalika Resort Lombok area with minimal tourism facilities and facilities, the idea to develop tourism area emerged to meet all the needs of tourism actors and tourists, including accommodation, tourist attraction and other public facilities (Disbudpar 2013).

The Mandalika Resort tourism area development policy in Lombok, which was formulated in the form of land acquisition of local communities covering 1,249.4 hectares, met resistance from the local community in Lombok as it was perceived as a marginalization towards the existence of local communities. The community considered that the policy was like a form of land grabbing, because they felt forced to sell their land that they had occupied for years at very cheap prices (SPI NTB 
2014). However the policy rationale, that is the inadequate tourism system and facilities, was actually logical as an effort by government to take responsibility to increase community welfare by relying on the tourism sector in the region. This means that policy making process of land acquisition in the Mandalika Resort area in Lombok, that was opposed by local communities as landowners, was not based on nothing, but was rather a response an existing policy issues (Parsons 2005:89).

The emergence of area development issue is a result of stagnant condition of the Mandalika Resort, in terms of both its infrastructure and tourism facilities. This issue is indeed worth to be the background of formulating land acquisition policy making process, because the development of tourism areas is inseparable from the provision of land for the construction of tourism facilities (Gelgel 2009:125). In addition, it is logical that the issue of regional development as a background requires the formulation of policies for land acquisition of local communities in the Mandalika Resort area in Lombok because, according to the UNDP study, tourism development has been recommended as a strategic alternative to overcome unresolved problems of community poverty with agricultural sector policies (Agus 2008:4). Moreover, the region is also a leading tourist destination thathas yet equipped with the provision of tourism infrastructure and facilities. This logic reasoning refers to the criteria for a policy issue that is feasible to respond through the process of policy formulation, which concerns the interests of many people and is related to the issue of power and the validity of a problem in society (Wahab 2011:40).

The issue of the development of the Mandalika Resort area has become a strategic one, considering that the area was designed by the Central Lombok District Government to create business and employment opportunities for the population, generate government revenues and encourage regional development (Disbudpar 2013). The expectations of the Central Lombok District Government regarding the existence of Mandalika Resort tourism are very rational, because tourism has become one of the strategic sectors to support regional economic improvement and community welfare (Kreishan 2010), thus confirming the results of Anna (2012) research, that tourism is a strategic priority for development policies in various regions and countries. This reason affirms tourism area development issue as a strategic and rational issue that must be responded to by the Local government to accelerate the realization of tourism as an alternative to the development of community economic welfare (Wever 2012).

Taking into account the duties and functions of local government as public institutions, which have the authority to determine public policies that are always oriented to solving problems and fulfilling public interests (Rachmat 2009:132), then the various responses of the local government to the issue of Mandalika Resort area development policies in Lombok, such as land acquisition of local communities to support the advancement of regional tourism, ideally should pay attention to the value of community interests as the main consideration in its indicators, such as the acceleration of community economic development, the provision of jobs, and the provision of other public facilities. However, the local government also anticipates the raise of public concerns about the negative impact of tourism on social, cultural and religious conditions that develop in people's lives (BTDC 2012).

The responsive steps of the local government in facing the issue of the development of the Mandalika Resort tourism area in Lombok referred to the meaning of public policy as a form of government intervention on public life, which is oriented on the following matters: 1) Anticipating, reducing or overcoming public problems what happens in the community; 2) Fulfilling the needs of individuals, families, groups or communities that they otherwise cannot fulfill individually except through collective action; 3) Improving human intrasocial relations by reducing individual or group social dysfunction caused by internal-personal and external-structural factors; 4) Improving the situation and environment that is conducive for efforts to implement and achieve community needs in accordance with human rights, dignity and dignity; 5) Exploring, allocating, and developing social resources for the sake of the welfare and justice in society (Suharto 2006:62).

The local government's goal to establish public welfare through tourism, as a substitute for agriculture's inability to overcome poverty problems, by responding to regional development issues and establishing superior tourism areas and implementing integrated tourism development models 
(Disbudpar 2013), as shown in the development of the Mandalika Resort area in Lombok, must be a primary consideration in facing policy issues in developing regional tourism areas, because one of the functions of the government as a public organization is to provide services to the community (Sarundajang 2000:55). However, the responsiveness of the local government should get community support, instead of resistance as they were perceived to be indifferent to the values of local community's interest in responding to the issue of regional tourism development. In the perspective of Rational Choice Theory, the policy making process of land acquisition for tourism areas development that are intended to overcome poverty is certainly a strategic and rational reason to pursue economic development of the community (Turner 2012:293), considering the responsibility of the local government as a public institution is the empowerment and economic well-being of the community (Muluk 2009:2).

Rationality of the local government's actions to respond tourism area development issue to accelerate the process of infrastructure and tourism facilities establishment so that the the regional tourism sector could immediately appear as a solution to overcome poverty, can also be understood through developmentalism who considered that tourism has demonstrated its ability as country's main foreign exchange machine (Agus 2008:15). However, Central Lombok Regency Government's decision to handle the management of tourism development in their own area were apparently not the right decision. The development shows no progress which then led to doubt in the emergence of tourism as a leading sector to bring welfare to the community and to increase foreign exchange income for the Central Lombok District Government itself.

Considering the economic criteria in regional tourism development policy, developmentalism theory view mentioned above is rational reason for the local government to formulate regional tourism area development policies, especially when local governments and local communities are unable to independently provide various facilities that support the security and comfort for tourists who come to visit the area. However, the dependence theory which explain that tourism business can lead to marginalization for local communities, both socially and economically, must be take into account during the regional tourism policies making process. Tourism requires intensive coordination between all interest groups to avoid conflicts of interest as tourism policies have triggered a number of conflicts and have no positive impact on community empowerment in the region (Wever 2012).

Along with the decentralization policy of regional tourism management, the development of tourism areas is one of the central issues that often gets a response from the local government, because it is an effort to improve the components of the tourism system in a particular geographical area (Gelgel 2009:125). The development of a tourism area is strongly supported by the existence and condition of the elements of the tourism system found in a tourism area, because the development of tourism areas is inseparable from efforts to increase the existence of tourism components which include: object power and attractions, accessibility, amenities, ancillary services, and tourism institutions (Gun 1994).

The emergence of tourism area development issue mentioned above certainly deserves to be the background of its policy formulation, because as an effort to seek the best possible action to solve problems or meet the demands of public interest, policy formulation does not commence out of the blue (Shaleh 2008). This means that public policy formulation does not occur in vacant conditions, but is influenced by several variables of people's lives, including social and economic conditions, prevailing political values, government structures, national norms and local cultural norms. Several criteria of public life worthy to be a rationale of policy making are: first, the issue has reached a certain critical point; secondly, the issue has reached a certain level of particularity that can have a dramatic impact; third, the issue concerns certain emotions seen from the interests of many people; fourth, the issue concerns the power and legitimacy in society; fifth, the issue concerns a fashionable problem where its position is difficult to explain but its presence is easily felt (Wahab 2011:40).

The existence of gaps or imbalances that occur in some variables in Lombok, such as poverty unsolved by agricultural policies, can be the cause of the emergence of tourism area development 
policy issues that demands public policy formulation. This departs from the perception that public policies formulation are dynamic in nature, instead of being carried out in a static space, and there is an existing context that demands the formulation (Soe'aidy 2008). This context is a series of processes that put public policy as critical in responding to the emergence of policy issues due to problems that occur in people's lives that are not able to be resolved by the community themselves thus government intervention is necessary (Nugroho 2014:105).

\section{Stages in public policy formulation}

The land acquisition policy for the development of Mandalika Resort area in Lombok, which faced resistance from the local community, was actually born through stages including problem identification, namely the spatial design of the Mandalika Resort area with an area of 1.249,4 hectares that are owned by locals in several points and also used by them for housing and farming. This problem is further affirmed by research findings on public perceptions in which locals do not agree with tourism development plans. Another problem faced in the development of this region is the absence of alternative to other strategic locations that have similar tourist attractions as Mandalika Resort area, ones with natural beauty of the beach with white sand that stretches from the west end to the east that is deemed as a superior area, as per Governor Decree No. 20 of 1989 (Karim 2008).

Among these two problems, according to the assessment of the local government, land tenure by local communities was finally seen as more strategic to be pursued in preparing its policy agenda. The alternative choice of policies is to control the land of the local community, namely: 1) Land acquisition from local community, 2) Collaboration between the local government and local communities in land use, 3) Loan scheme of local community land by local government for a certain period of time without any obligation to sell. However, considering these reasons: 1) Tourism development process acceleration, 2) Regional economic development interest, 3) Investor demands, it was finally decided that land acquisition is to be pursued in local government policy for the development of Mandalika Resort area in Lombok (SPI NTB 2014).

Considering the land acquisition policy making process for the development of the Mandalika Resort area in Lombok above, which begins with identifying problems, determining policy agendas, choosing alternative policies, and determining policies; despite getting local resistance, it has actually gone through the proper administrative process and established through a series of actions (Salusu 2003:47). Local government's problem mapping effort is the ideal initial step in designing Mandalika Resort tourism area development policy, as the starting point of every policy making is problem identification. Understanding of the problem, which in the case of tourism area development is opposed by locals and spatial planning that are still in the control of the local community, can help find hidden assumptions, diagnose its causes, map possible objectives, combining conflicting views and drafting new policies. Comprehensive understanding of policy isues is fundamental to formulate policy that could acommodate the interests of all policy stakeholders as each of them has a different perspective. What is considered a problem and how the problem is defined will depend on the way the stakeholders deal with policy issues (Parsons 2005:89).

In the development of Mandalika Resort tourism area in Lombok, local's land tenure is seen as an obstacle in tourism facilities development. Therefore the effort to establish Mandalika Resort as a leading tourist area, consisting of tourist attractions, tourism promotion, tourism facilities and services, transportation facilities and services, and the tourism community (Hadinoto 1996:32) is stagnated, actually too simple to see factors that influence regional tourism development, because it has an integrated structure with local life (Sharpley \& Craven 2001). In tourism policy making process, partial understanding of the problem in addition to a top-down approach will only result in policies that can cause harm to the environmental balance and social economic dimensions (Mohammed 2014).

In responding to stagnant tourism development, local government should understand that tourism is a complex system, which is not only seen in the sustainability of the policies, but also on policy issues and networks (Ricci 2015). Therefore, various plans and policies for tourism development must consider 
a potential network instead of a segmented policy, because tourism policy cannot be understood by summing up simple policy themes but through holistic assessment using multiple criteria analysis and impact (Jordan \& Turnpenny 2015) in order to anticipate adverse consequences. Thus, the process of formulating tourism area development policies can give birth to a policy decision that can support the progress and development of regional tourism that brings benefits to all interest groups.

The underdevelopment of tourism in the Mandalika Resort area in Lombok is evident from the lack of facilities, that is caused by problems over land status which are still under local communities. This is identified as problem as local government must receive responses about policy agenda. However, one indicator is inadequate to make policy result in line with the existing problems. Multiple crieria shall be used, including cost and benefit analysis. Comprehensive introduction to policy problem can help actors to come up with effective and selective policy alternatives as well as assuring that the problem can only be resolved through public policy approach (Dunn 2000:108).

According to Patton (1993:3) problem identification process is important identifying alternative policies. In the case of Mandalika Resort area in Lombok, land tenure by the local community is identified as a problem in the development process. Therefore it should be studied in depth through various aspects, causes, consequences, and disadvantages to the development of regional tourism as policy problem related to the discrepancy in values, needs, or opportunities can be corrected or achieved later through policy actions. This aspect must be seen through economy, politics and social values (Jordan \& Penny 2015). Problems in tourism development are usually complex and related to many factors (Niekerk 2014).

The perception of locals' land tenure as a policy problem for the development of the Mandalika Resort area in Lombok, was followed up at the policy agenda stage based solely on the consideration of local government's interest rather than as results of objective analysis through various approaches and criteria. This will result in errors during policy determination stage and resistance from interest groups who feel disadvantaged by the policy decision will emerge as the consequence. To prevent this mistake, there needs to be a forum to formally discuss and analyse policy alternatives during policy agenda formulation stage (Sulistio 2012:178) .

Ideally, the selection of land ownership issue in Mandalika Resort area as a problem should have gone through a competition with other issues, because what is considered a problem by certain stakeholders is not necessarily considered a problem by the others. The views of stakeholders on a problem cannot be separated from a frame which is influenced by ideas, values, and stakeholder beliefs (Subarsono 2016:10). In a pluralist perspective, defining the problem and establishing a policy agenda is basically the result of a comeptitive process between different groups (Parsons 2005:127). The power to influence volatility of an issue or the entry and exit of issues on the policy agenda is considered more scattered than concentrated. Contrary to this, land acquisition policy formulation as an issue in developing Mandalika Resort area was originated only from local government's perspective therefore not all parties can influence this policy agenda. Problem identification and policy agenda setting are only intended to accommodate existing policy decisions, which in policy formulation model theory are referred to as the Garbage Can model (Kingdom 2003).

There were several alternatives that emerged during the formulation of Mandalika Resort area land acquisition policy, namely the acquisition of land through purchase, cooperation and loans. But in determining policy alternatives, the local government does not involve other stakeholders such local community as land owner. The rise of public opposition to the policy because they felt left out and disadvantaged is a risk that often faced by policy decision that use elitist policy formulation models (Nogroho 2014). The process of formulating regional tourism policies that flow top-down from the will of the elite, in the end can lead to the rejection of local communities towards regional policy decisions (Belletti 2015).

The process of identifying various possible policy alternatives to address issues is very important to get the best possible outcome. This is also a distinguishing criterion between policy and 
decision (Patton 1993:3). Policy is the chosen from various alternatives while decision possess no alternatives. Various policy alternatives that emerge must also be evaluated, including giving weight and rank of each alternative that has been identified. According to Islamy (2009:92) choosing policy alternative is the activity of compiling and developing a series of necessary action to solve policy problems. In addition, tourism development is a very complex issue that covers not only the issue of sustainability, social, cultural and economic impacts, but also its policy networks. Therefore, the choice in formulating tourism development policies must consider potential networks rather than fragmented policies (Farsari 2011).

In terms of the land acquisition policy making for the Mandalika Resort area development in Lombok, which is intended to accommodate existing decision, the other three policy alternatives were not comprehensively studied and did not go through a fair competition. Therefore, relationship between policy capacity and the characteristics of the problem were neglected during the determination phase of policy choices. While according to William (2000:239), six criteria must be considered in determining policy alternatives: objectives, costs, benefits, constraints, side effects, time and risk or uncertainty. To get the best legitimate outcome with benefits for stakeholders, each alternative should be reviewed comprehensively in all aspects that have influence or that can be influenced by each choice, both based on rational and political considerations (Sofyan 2001).

Considering the desire of local government about Mandalika Resort area, the decision to enact land acquisition policy is a rational choice (Tunner 2012), because it is expected to create jobs for the community, increase community's income and local government's revenues, as well as for area development. The rationality of this choice also in line with developmentalism who considers that the tourism has demonstrated its ability to be the main source of foreign exchange for the state/ government in carrying out its functions. In addition, the land acquisition policy has actually been prepared in advance based on the compromise and negotiation of the local government and local corporation, and therefore deemed to be a "policy as solution find problem rather than vice-versa" (Kingdom 2003). As a result, the policy makers are actually looking for problems as justification for the policy decisions made instead (Peters 2004:61).

Taking into account the policy making process, the formulation of land acquisition policy for the development of Mandalika Resort area was actually carried out through garbage can model, as the policy was decided before the policy formulation process commenced, namely Governor Decree Number 20 of 1989 concerning the designation and land usage as a tourism area. Therefore, based on this garbage can model, the policy formulation process is not actually intended to find the best policy alternative to solve land tenure issues that is considered a problem for tourism development, but merely as a courtesy to support previously agreed decisions.

The application of the garbage can model in the formulation of land acquisition policies for the development of Mandalika Resort area is not an ideal mechanism to find the best policy in overcoming policy issues as it has limited criteria and limited considerations in each policy choice. While in contrary, policy formulation requires multi criteria and analysis theory. In the garbage can model, policy makers usually decide the policies prior to finding problems that are in accordance with the pre-made policies. In this model, the process of policy formulation does not begin with the identification of problems, but begins with making decisions (Kingdom 2003).

The resistance of local people in Lombok to the formulation of land acquisition policy for the development of Mandalika Resort area due to lack of consideration to their interests during the policy making process, confirmed the theory of Delgado and Palomeque (2012) that tourism area development policies which merely put emphasis on economic benefits and business as an indicator of rational choice, tends to marginalize the existence of local communities. The same view was reitrated by Nunkoo (2013) who stated that prioritizing a political economy approach in policy making would result in the loss of public confidence in the government as the policy maker (Biaggio 2015), because the community as always harmed by the policy, so opposition from the society against the policy is inevitable. 
Local community's resistance against regional tourism development policy decisions in Lombok, such as blocking the development process and conducting demonstrations at NTB Governor's Office rejected tourism development in the area (Lombok Post 2012), is because they are forced to accept the policy decided by local government who have put public policy formulation into a strategic phase of the policy process. This led to government's ability to coerce all interest groups to be submissive and obedient, even though they feel disadvantaged by the policy (Prasetyo 2011). This is not an ideal policy formulation result, as even though policy to solve public provlems can be intervened by various interest groups, the policy decision must moderate the interests of all stakeholders including government, private entities, and community. Therefore no one is in disadvantage, especially in the context of tourism development which has placed local communities as the main actors (Mwesiumo \& Halpern 2016).

Applying patricipatory policy formulation model with relational approach can be a solution to moderate various tensions, conflicts, and even resistance against regional tourism development policies, as shown in the land acquisition policy for the development of Mandalika Resort area in Lombok. This model can improve policy formulation process as it connects actors, structures, dynamics, and characteristics of locals; enable a detailed assessment on sustainability and changes that will occur in every response towards local tourism development policy; and the policy alternatives are not based solely on political economy factor but also based on social construction of the local community (Bramwell \& Meyer 2007).

\section{Conclusion}

The birth of regional tourism area development policies in Lombok, which were opposed by locals, was motivated by local government's desire to establish tourism sector as an alternative source for economic prosperity and a tool to alleviate poverty. This policy had undergone few process: identifying problems, determining policy agendas, mapping and selecting alternative policies, and determining policies. This shows that the land acquisition policy formulation process was carried out systematically, but the enacted policy was apparently not the ideal choice because it did not moderate the interests of all stakeholders. Moreover, the interests of local communities as the main actors in this policy, whose interest should be the main consideration, are in fact marginalized.

Even though the regional tourism policies had undergone a systematic process, if the policy product is not based on a comprehensive study and is not providing opportunity for local communities to articulate their interests, the decision is thus lacking in legitimacy. As a result, it will be opposed by the society instead of supported. Marginalization of local community in various regional tourism policies will put the goal to make tourism a leading sector for regional economy development in danger. When local communities are not involved in the policy formulation process, their interests will be neglected during policy formulation process. This will result in a resistance against the policy by local communities.

\section{References}

Azhar MA (2013) Public policy and public policy resistance: Critical analysis toward badung regency government policy in operating mengwi terminal. Jurnal SPEKTRUM 14 (2):1-10.

Belletti G (2015) Geographical indications, public goods, and sustainable development: The roles of actors' strategies and public policies. World Development 20 (1):1-13.

Biaggio CD (2015) Investigating regional identities within the pan-alpine governance system: The presence or absence of identification with a "Community of Problems" among local political actors. Environmental Science and Policy 49 (1):45-56.

Bramwell B \& Meyer D (2007) Power and tourism policy relations in transition. Annals of Tourism Research 34 (3):766-788.

Checkland P (1993) System Thinking, Systems Practice. New York, Brisbane, Toronto: John Wiley \& Sons. 
Delgado AT \& Palomeque FL (2012) The growth and spread of the concept of sustainable tourism: The contribution of institutional initiatives to tourism policy. Tourism Management Perspectives 4:1-10.

Dunn WN (2000) Pengantar Analisis Kebijakan Publik. Yogyakarta: Gadjah Mada University Press.

Farsari I (2011) Complexity in tourism policies: A cognitive mapping approach. Annals of Tourism Research 38 (3):1110-1134.

Gelgel IP (2009) Industri Pariwisata Indonesia Dalam Globalisasi Perdagangan Jasa (GATS-WTO): Implikasi Hukum dan Antisipasinya. Bandung: Refika Aditama.

Gun CA (1994) Tourism Planning: Basics Concept Cases. Third Edition. Washington DC: Taylor \& Prancis.

Hadinoto K (1996) Perencanaan Pengembangan Destinasi Pariwisata. Jakarta: Universitas Indonesia Press.

Islamy MI (2009) Prinsip-Prinsip Perumusan Kebijaksanaan Negara. Jakarta: Bumi Aksara.

Jordan AJ \& Turnpenny R (2015) Tools of Public Formulation: Actors, Capacities, Veneus, and Effects. Edward Elgar Publisher.

Karim A (2008) Kapitalisasi Pariwisata dan Marginalisasi Masyarakat Lokal di Senggigi. Yogyakarta: Genta Press.

Kingdom JW (2003) Agendas, Alternativ, and Public Policies. New York: Longman.

Kreishan FM (2010) Tourism and economic growth: The case of Jordan. European Journal of Social Sciences 15 (2):63-68.

Manoppo PT (2012) Modal sosial masyarakat korban dalam konteks kebijakan pembebasan tanah proyek Banjir Kanal Timur (BKT) di DKI Jakarta. Jurnal Magister Manajemen ASMI 1 (1):1-28.

Mohammed AJ (2014) Linking outputs and outcomes from devolved forest governance using a Modified Actor-Power-Accountability Framework (MAPAF): Case study from Chilimo forest, Ethiopia. Forest Policy and Economics Forest Policy and Economics Journal 39 (1):21-31.

Muluk MK (2009) Peta Konsep Desentralisasi dan Pemerintahan Daerah. Surabaya: ITS Press.

Mwesiumo D \& Halpern N (2016) Interfirm conflicts in tourism value chains. Tourism Review Journal 71 (4):259-271.

Niekerk M V (2014) Advocating community participation and integrated tourism development planning in local destinations: The case of South Africa. Journal of Destination Marketing \& Management 3 (1):82-84.

Nugroho R (2014) Kebijakan Publik di Negara-Negara Berkembang. Yogyakarta: Pustaka Pelajar.

Nunkoo R (2013) Political economy of tourism: Trust in government actor, political support, and their determinants. Annals of Tourism Research 38 (3):964-988.

Parsons W (2005) Public Policy. Jakarta: Prenada Media.

Patton CV (1993) Basic Method of Policy Analysis and Planning. London: Prentice Hall.

Peters G (2004) American Public Policy: Promice and Performance. New Jersey: Chatam House.

Prasetyo B (2011) Orientasi aktor dalam perumusan kebijakan publik. Masyarakat, Kebudayaan dan Politik 21 (2):115-130.

Rakhmat (2009) Teori Administrasi dan Manajemen Publik. Jakarta: Pustaka Arif.

Ricci L (2015) Climate risks in West Africa: Bobo-Dioulasso local actors' participatory risks management framework. Environmental Sustainability Journal 13 (3):42-48. 
Salusu J (2003) Pengambilan Keputusan Stratejik untuk Organisasi Publik dan Organisasi Nonprofit. Jakarta: Grasindo.

Sarundajang (2000) Arus Balik Kekuasaan Pusat ke Daerah. Jakarta: Pustaka Sinar Harapan.

Sharpley R \& Craven B (2001) The 2001 foot and mouth crisis - Rural economy and tourism policy implications. Tourism Journal 4 (6):527-537.

Sidemen IP (2012) Dampak Pembebasan Lahan Pembangunan Kota Baru Lampung Terhadap Kondisi Sosial dan Ekonomi Petani Penggarap Lahan Eks-Lipi. Laporan Hasil Penelitian. Lampung: Jurusan Sosiologi Fisip Universitas Lampung.

Sin HL (2014) Responsibility for tourism: The problem with going to a local in the field of communitybased tourism in Thailand. Geoforum Journal 5 (1):96-106.

Soe'aidy S (2008) Analisis Kebijakan Tentang Relasi Negara, Pasar, dan Masyarakat dalam Perumusan Kebijakan Publik: Kasus Malang Town Square. Dissertation, Universitas Airlangga, Surabaya.

SPINTB (2014) Jeritan Petani Selatan di Balik Indahnya Kampanye Pariwisata Lombok. [Accessed 20 January 2014]. http://ntbbicara.blogspot.com/2014/01/jeritan-petani-selatan-di-balik.html.

Subarsono A (2016) Kebijakan Publik dan Pemerintahan Kolaboratif: Isu-Isu Kontemporer. Jakarta: Gava Media.

Suharto E (2006) Analisis Kebijakan Publik: Panduan Praktis Mengkaji Masalah dan Kebijakan Sosial. Bandung: Alfabeta.

Sulistio EB (2012) Studi Formulasi Kebijakan Penataan Sistem Transportasi Perkotaan di Kota Bandar Lampung. Laporan Hasil-hasil Penelitian dan Pengabdian Kepada Masyarakat. Lampung: Fisip Universitas Lampung.

Tsartas P (2003) Tourism development in greek insular and coastal areas: Sociocultural changes and crucial policy issues. Journal Of Sustainable Tourism 11 (2):116-132.

Turner BS (2012) Citizenship and Social Theory. London: Sage.

Wahab SA (2011) Analisis Kebijaksanaan: Dari Formulasi ke Implementasi Kebijaksanaan Negara. Jakarta: Bumi Aksara.

Wever G (2012) Decentralization and participation in integrated coastal management: Policy lessons from Brazil and Indonesia. Journal of Ocean and Coastel Management 66 (2):63-72. 